\title{
Laurus nobilis L.: assessment of the cytotoxic and genotoxic potential of aqueous extracts by micronucleus and Allium cepa assays
}

\author{
Mayara Christine Silva ${ }^{1}$, Aline Ferreira Matos ${ }^{1}$, Hataânderson Luíz Cabral dos Santos ${ }^{1}$, \\ Jennifer Vieira Gomes, ${ }^{1}$, Danilo Giovanni Narciso Pastura ${ }^{1}$, Gabriela Lopes Pereira ${ }^{1}$, \\ Ellen Borges da Rocha ${ }^{1}$, Mayara de Jesus Costa Larangeira1, Raphael Santiago Alves ${ }^{1}$, \\ Leonardo de Oliveira Bastos ${ }^{1}$, Helcio Resende Borba ${ }^{1}$, Viviane Moreira de Lima ${ }^{\circledR *}$
}

${ }^{1}$ Department of Animal Biology, Laboratory of Genotoxic Activity of Plants, Institute of Biological Sciences and Health, Federal Rural University of Rio de Janeiro, Seropédica, RJ, Brazil

\begin{abstract}
Laurus nobilis L. is a large shrub belonging to the Lauracea family. Its leaves are widely used for food seasoning as well as in folk medicine. Various studies have demonstrated the antiproliferative, antifungal and antibacterial effects of Laurus nobilis, but no studies have investigated the genotoxic effect of the aqueous extract of the plant. The objective of this study was to analyze the genotoxic potential of an aqueous extract of leaves, using the Allium cepa assay and mouse peripheral blood cell micronucleus test. The results showed that the extract did not have any genotoxic activity, but cytotoxic activity was observed in the two experimental models used. The extract had an antiproliferative effect, detected through the reduction of the mitotic index and the polychromatic/normochromatic erythrocyte (PCE/NCE) ratio. The tests also demonstrated a large number of cells undergoing apoptosis and with nuclear abnormalities related to cell death processes. These results can be explained by the presence of phenolic compounds, saponins, flavonoids and alkaloids, detected in the phytochemical analysis of the extract. Therefore, the extract from L. nobilis in the form generally used by the population does not pose risks related to its genotoxic potential, and also contains components with apoptotic and antigenotoxic potential.
\end{abstract}

Keywords: Laurus nobilis. Allium cepa. Micronucleus. Genotoxicity. Cytotoxicity.

\section{INTRODUCTION}

Laurus nobilis L., popularly known as bay laurel, sweet bay, bay or laurel, is a large shrub belonging to the Lauracea family, native to Asia but now cultivated in many countries. In Brazil, the main growing regions are the South and Southeast. Its leaves are widely used for food seasoning, as well as in folk medicine due to the digestive, carminative, antispasmodic, astringent, emmenagogue, diaphoretic and antiseptic properties of extracts (Kaurinovic, Popovic, Vlaisavljevic., 2010; Dias et al., 2014).

Although Kivçak and Mert (2002) only observed the presence of cytotoxic effects in the hexane extract of Laurus nobilis leaves, more recent studies have

\footnotetext{
*Correspondence: V. M. Lima. Departamento de Biologia Animal, Instituto de Ciências Biológicas e da Saúde, Universidade Federal Rural do Rio de Janeiro, BR 465 - Km 7, CEP: 23897-000. E-mail: vilima@ufrrj.br
}

demonstrated that the aqueous extract of the leaves is effective in reducing the population of the mite Phytoseiulus macropolis, besides having antiproliferative effect on some tumor cell lines (Veronez, Sato, Nicastro, 2012; Dias et al., 2014). Finally, some researchers have demonstrated the antifungal and antibacterial activity of the essential oil obtained from $L$. nobilis leaves (Rafiq et al., 2016; Peixoto et al., 2017).

The essential oil extracted from $L$. nobilis has been widely studied for its biological activities and to determine its chemical composition. However, to the best of our knowledge there are no published studies of the genotoxic effect of the aqueous extract of these leaves. This investigation is necessary to assure that the extract, as typically used in folk medicine, can be administered with relative safety for therapeutic purposes, mainly for extended periods (Macedo et al., 2008; Castro et al., 2009). 
Therefore, considering the importance of toxicogenetic investigation, the aim of this study was to investigate the cytotoxic and genotoxic potential of the aqueous extract of $L$. nobilis leaves, using the Allium cepa assay and mouse peripheral blood mononuclear cell test.

\section{MATERIAL AND METHODS}

\section{Sample collection and identification}

Leaves of L. nobilis L. at different stages of development were collected in the Jacarepaguá district of Rio de Janeiro, RJ. The botanical material was recognized by the herbarium technician Thiago Azevedo Amorim of the Botany Department of Rio de Janeiro Federal Rural University (UFRRJ) and a voucher specimen was deposited in the university's herbarium under number RBR 36.379.

\section{Preparation of the aqueous extract of $L$. nobilis leaves}

Immediately after collection, the leaves were taken to the Laboratory of Plant Genotoxic Activity (LAGEP) of UFRRJ, where they were spread on a table and left at room temperature $\left(28{ }^{\circ} \mathrm{C}\right)$ in an area protected from sunlight for $72 \mathrm{~h}$ (air-drying). The naturally dried leaves were then placed in an amber flask until the moment of preparing the crude aqueous extracts. The leaves were ground and placed in glass vials, into which warm distilled water was poured $\left(90^{\circ} \mathrm{C}\right)$. The vials were capped immediately and maintained in this condition for at least 10 minutes to obtain the extracts. After being cooled to room temperature, the crude extracts were filtered through cotton cloth to remove residues. Fresh extracts, at concentrations of 1.5 and 3\% (Allium cepa assay) and 5\% (micronucleus assay and phytochemical analysis) were prepared daily, just before use in the experiments.

\section{Phytochemical analysis of the extracts}

To identify and quantify the chemical constituents present in the aqueous extracts, phytochemical analysis was carried out with $50 \mathrm{mg}$ of the aqueous extract, dried by evaporation in water bath at $50{ }^{\circ} \mathrm{C}$, through the techniques described by Trease and Evans (1989), Matos (2009), Cai, Shi and Gao (2011) and Morsy (2014). The screening was performed to quinones, reducing sugars, saponins, sesquiterpenlactones and other lactones, phenolic tannins, steroids and triterpenoids, cardiac glycosides, polysaccharides, purines, flavonoids and alkaloids. For detection of quinones, the extract was dissolved in ethyl ether followed by addition of ammonium hydroxide. The presence of quinones was determined by red color in the aqueous phase. The reducing sugars were detected by the reaction of Benedict's reagent. The presence of saponins was observed by the formation of froth in a test tube upon vigorous shaking using diluted samples. Sesquiterpenlactones and other lactones were determined by dissolving the extract in methanol and adding hydroxylamine hydrochloride and $\mathrm{KOH}$. After heating, the solution was acidified with $\mathrm{HCl}$ followed by $\mathrm{FeCl}_{3}$ addition. The presence of sesquiterpene lactones and other lactones was verified by violet color. For detection of steroids and triterpenoids, the sample was dissolved in chloroform. The appearance of evanescent blue color (sterols) and green color (tripterpenoids) after treatment of the chloroform layer with acetic anhydride and concentrated $\mathrm{H}_{2} \mathrm{SO}_{4}$ in series indicated positive reactions. The cardiac glycosides were detected by using Kedde's reagent. The presence of polysaccharides was verified by using lugol. For detection of purines, the extract was hydrolyzed with $\mathrm{HCl}$ followed by addition of $\mathrm{H}_{2} \mathrm{O}_{2}$. After evaporation in a water bath and addition of a few drops of $\mathrm{NH}_{4} \mathrm{OH}$, the presence of purines was determined by the appearance of violet color. The presence of alkaloids was determined by using Wagner's reagent. Class I and II of flavonoids were detected by acidulation and neutralization of the extract with the appearance of different colors at $\mathrm{pH}$ specific for the different classes. For the detection of phenolic and tannins, the sample was dissolved in distilled water and drops of $\mathrm{FeCl}_{3}$ were added. The presence of phenolic tannins was determined by the presence of a blue color.

\section{Analysis of total flavonoids and phenolics content}

To determine the total flavonoids and phenolics content, the dry extract mass was obtained by infusing $50 \mathrm{~g}$ of crushed leaves in $200 \mathrm{~mL}$ of water, followed by heating in an oven at $50^{\circ} \mathrm{C}$ until constant weight.

The total flavonoid content was measured by the method described by Barroso et al. (2011) with some modifications, using as complexing agent aluminum chloride. Quercetin was the standard used to construct the calibration curve for the quantification.

The determination of the total phenolic concentration was performed according to the method described by Salgueiro and Castro (2016), based on a standard curve of commercial gallic acid and using the colorimetric method with Folin-Ciocalteu reagent.

\section{Allium cepa assay}

For these tests, organically grown onions with diameter of approximately $2.0 \mathrm{~cm}$ were obtained from a 
local produce market. The outer layer of each bulb was removed with a paring knife without damaging the root buds.

The bulbs were initially placed in a container holding distilled water for 48 hours to allow the roots to grow, with daily water exchange. Then the bulbs were separated into two control groups and two treatment groups, each with five onions. The negative control group remained in the distilled water, the treatment groups were immersed in two L. nobilis leaf extract solutions (concentrations of $15 \mathrm{mg}$ $\mathrm{mL}^{-1}$ and $30 \mathrm{mg} \mathrm{mL}^{-1}$ ) and the positive control group was immersed in a solution containing ethyl methanesulfonate (EMS, $25 \mathrm{mM}$ ). EMS is a highly efficient mutagenic agent, which acts directly on DNA molecules through its alkylation activity. The solutions were exchanged daily for all groups and the temperature was maintained at $25^{\circ} \mathrm{C}$.

For each treatment, root tips, between 2 and $2.5 \mathrm{~cm}$ in length, were removed from the bulbs after 48 hours of exposure to the respective solutions and used to prepare slides according to the method described by de Castro e Sousa et al. (2017), with modifications. Five root tips were removed from each bulb, fixed in an ethanol: glacial acetic acid solution at $3: 1(\mathrm{~V} / \mathrm{V})$ and stored at $4{ }^{\circ} \mathrm{C}$ until the moment of preparing the slides. Five slides were prepared for each bulb, using five different root tips (one slide for each one). The root tips were washed with distilled water twice for 5 minutes, hydrolyzed in $\mathrm{HCl} 5 \mathrm{~N}$ for 30 minutes, washed again twice in distilled water for 5 minutes and then placed on the slides with tweezers. The subapical meristems were fragmented with a scalpel, stained with $2 \%$ acetic orcein, and covered with a coverslip.

All slides were coded and evaluated under a common optical microscope with 100X magnification. The parameters used to determine the genotoxic and cytotoxic potential of the extracts were the presence of chromosome and cell alterations as well as changes in the mitotic index. A total of 1,000 cells were analyzed per bulb, or 5,000 cells for each group. With the exception of the mitotic index, expressed as a percent, the results are expressed in absolute terms. The most frequent anomalies are shown in the micrographs.

\section{Micronucleus assay}

Male Swiss albino mice aged 10 weeks, weighing $25 \mathrm{~g}$, were provided by the Central Animal House of UFRRJ. During the experiment, the animals were kept in polyethylene cages, each one with six animals, at a constant temperature of $(22 \pm 1){ }^{\circ} \mathrm{C}$ and $12 \mathrm{~h}$ light/dark cycle. Standard food pellets and water were provided ad libitum.
The micronucleus assay was performed according to Andrade, Perazzo and Maistro (2008a), with modifications. Assays were carried out with 6 animals/ group and with the exception of the positive control, the treatment was performed intragastrically. Group I animals received a single dose of $2,000 \mathrm{mg} / \mathrm{kg}$ of aqueous extract of L. nobilis leaves; Group II (positive control) animals received a single dose of cyclophosphamide at $50 \mathrm{mg} / \mathrm{kg}$ intraperitoneally; and Group III (negative control) received only water. A $20 \mu \mathrm{L}$ aliquot of peripheral blood was collected from each animal at $48 \mathrm{~h}$ and $72 \mathrm{~h}$ after treatment, by terminal bleeding from the retro-orbital plexus. Samples were deposited on a slide to prepare the smears, which were fixed in methanol and stained with Leishman's solution.

For each Swiss mouse, 4,000 polychromatic erythrocytes (PCE) were scored (2,000 cells from the $48 \mathrm{~h}$ blood sample and 2,000 cells from the $72 \mathrm{~h}$ blood sample). For evaluation of the cytotoxic potential, 1,000 cells were analyzed per animal to determine the polychromatic/ normochromatic erythrocyte (PCE/NCE) ratio. All slides were coded and evaluated under a common optical microscope with 100X magnification.

This study was approved by the Ethics Committee on Animal Use of the Biological Sciences and Health Institute of UFRRJ (protocol no. 011/2014).

\section{Statistical analysis}

The data were analyzed by the Chi-square $\left(\chi^{2}\right)$ test with probability $<0.05$, using Yates correction, employing the Bioestat 5.0 program

\section{RESULTS}

\section{Allium cepa system}

The results showed that the aqueous extracts obtained from the L. nobilis leaves did not have genotoxic potential against meristematic cells of Allium cepa after treatment for 48 hours, since no aberrations of the chromosomes or micronuclei were observed. Besides this, the $A$. cepa cells treated with the extract, at the two concentrations tested, presented a significantly lower number of buds, as well as alterations that are characteristic of EMS, the positive control (Tables I and II). The cells submitted to treatment with EMS stood out for the presence of a larger number of nucleoli and greatly enlarged volume (Figure 1C).

However, cytotoxic activity of the extract was detected at both concentrations (Tables I and II). It was possible to observe a large number of cells undergoing 
apoptosis and nuclear alterations related to cell death processes (Figures 1B and 1D).

Besides these alterations, at the concentration of $15 \mathrm{mg} \mathrm{mL}^{-1}$ the cytotoxic activity was accompanied by a substantial reduction of the mitotic index compared to the negative and positive controls (Table I).

\section{Micronucleus test}

Tables III and IV report the results of the frequency of micronucleated PCE and the PCE/NCE ratio in the peripheral blood of mice submitted to treatment with a single dose of $2,000 \mathrm{mg} / \mathrm{kg}$ of the aqueous extract of L. nobilis.

TABLE I - Cell changes and mitotic index in A. cepa submitted to different treatments

\begin{tabular}{lccccccc}
\hline TREAT & CONC & NC & NB & MN & A P & NA & MI (\%) \\
\hline NEG C & Distilled water & $391^{(\mathrm{c})}$ & $33^{(\mathrm{b})}$ & $28^{(\mathrm{b})}$ & $50^{(\mathrm{c})}$ & $107^{(\mathrm{c})}$ & $1.18^{(\mathrm{b})}$ \\
EMS & $25 \mathrm{mM}$ & $1451^{(\mathrm{b})}$ & $19^{(\mathrm{b})}$ & $33^{(\mathrm{b})}$ & $3^{(\mathrm{b})}$ & $24^{(\mathrm{b})}$ & $0.98^{(\mathrm{b})}$ \\
LN AQ & $15 \mathrm{mg} \mathrm{mL}^{-1}$ & $370^{(\mathrm{a})}$ & $9^{\text {(a) }}$ & $1^{(\mathrm{a})}$ & $380^{(\mathrm{a})}$ & $1497^{(\mathrm{a})}$ & $0.14^{(\mathrm{a})}$ \\
\hline
\end{tabular}

(a) (b) and (c) different letters in the same column differ from each other $(\mathrm{P}<0.05)$ according to the $\chi^{2}$ test; TREAT-treatment; NEG $\mathrm{C}$ - negative control; EMS - positive control; LNAQ - L. nobilis aqueous extract; CONC - concentration; NC - nucleoli changes; NB - nuclear bud; MN - multiple nucleoli; AP - apoptosis; NA- nuclear abnormalities; MI - mitotic index. 5000 cells for each treatment were analyzed.

TABLE II - Cell changes and mitotic index in A. cepa submitted to different treatments

\begin{tabular}{lccccccc}
\hline TREAT & CONC & NC & NB & MN & AP & NA & MI (\%) \\
\hline NEG C & Distilled water & $339^{(\mathrm{c})}$ & $66^{(\mathrm{b})}$ & $24^{(\mathrm{a})}$ & $4^{(\mathrm{b})}$ & $61^{(\mathrm{c})}$ & $3.52^{(\mathrm{a})}$ \\
EMS & $25 \mathrm{mM}$ & $1000^{(\mathrm{b})}$ & $76^{(\mathrm{b})}$ & $91^{(\mathrm{b})}$ & $2^{(\mathrm{b})}$ & $12^{(\mathrm{b})}$ & $2.04^{(\mathrm{b})}$ \\
LN AQ & $30 \mathrm{mg} \mathrm{mL}^{-1}$ & $193^{(\mathrm{a})}$ & $27^{(\mathrm{a})}$ & $15^{(\mathrm{a})}$ & $277^{(\mathrm{a})}$ & $1953^{(\mathrm{a})}$ & $3.16^{(\mathrm{a})}$ \\
\hline
\end{tabular}

(a) (b) and (c) different letters in the same column differ from each other $(\mathrm{P}<0.05)$ according to the $\chi^{2}$ test; TREAT-treatment; NEG $\mathrm{C}$ - negative control; EMS - positive control; LNAQ - L. nobilis aqueous extract; CONC - concentration; NC - nucleoli changes; NB - nuclear bud; MN - multiple nucleoli; AP - apoptosis; NA- nuclear abnormalities; MI - mitotic index. 5000 cells for each treatment were analyzed.
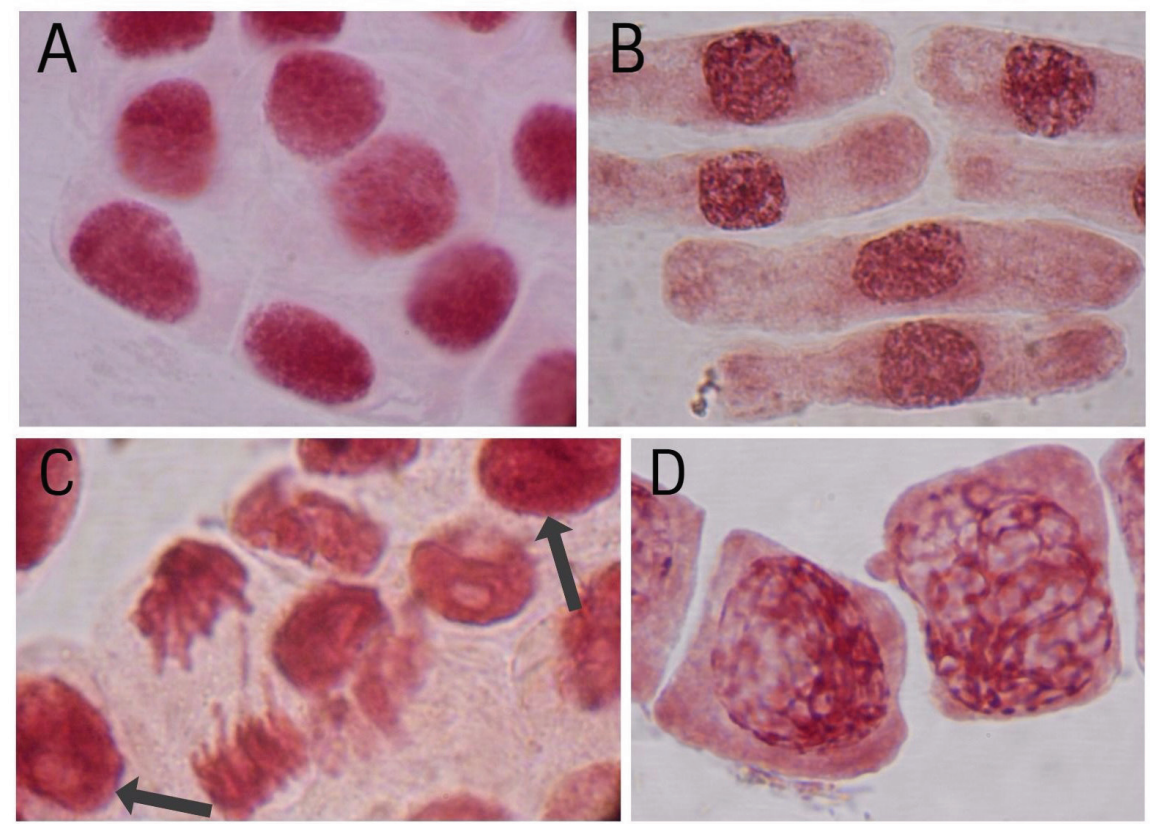

FIGURE 1 - Changes in A. cepa cells submitted to different treatments: A- normal cells, B - apoptosis, C- nucleoli changes (arrows) - positive control, D- nuclear abnormalities. 
Laurus nobilis L.: assessment of the cytotoxic and genotoxic potential of aqueous extracts by micronucleus and Allium cepa assays

TABLE III - Frequency of micronucleated polychromatic erythrocytes (MNPCEs) in mice $48 \mathrm{~h}$ after the different treatments

\begin{tabular}{|c|c|c|c|c|c|}
\hline \multirow{2}{*}{ Treatment } & \multirow{2}{*}{$\begin{array}{c}\text { Number of cells } \\
\text { analyzed }\end{array}$} & \multirow{2}{*}{ PCEs } & \multicolumn{2}{|c|}{ MNPCES } & \multirow{2}{*}{$\begin{array}{c}\mathrm{PCE} / \mathrm{NCE} \\
\text { ratio }\end{array}$} \\
\hline & & & $\mathrm{N}^{0}$ & $\%$ & \\
\hline Positive control & 12000 & 11958 & $42^{(\mathrm{c})}$ & 0.35 & $0.002^{(\mathrm{c})}$ \\
\hline Negative control & 12000 & 11978 & $22^{(a)}$ & 0.23 & $0.05^{(\mathrm{b})}$ \\
\hline Aqueous extract & 12000 & 11982 & $18^{(a)}$ & 0.15 & $0.017^{(\mathrm{a})}$ \\
\hline
\end{tabular}

(a) (b) and (c) different letters in the same column differ from each other $(\mathrm{P}<0.05)$ according to the $\chi^{2}$ test; PCEs - polychromatic erythrocytes; NCE - normochromatic erythrocytes; MNPCEs - micronucleated polychromatic erythrocytes.

TABLE IV - Frequency of micronucleated polychromatic erythrocytes (MNPCEs) in mice $72 \mathrm{~h}$ after the different treatments

\begin{tabular}{|c|c|c|c|c|c|}
\hline \multirow{2}{*}{ Treatment } & \multirow{2}{*}{$\begin{array}{c}\text { Number of cells } \\
\text { analyzed }\end{array}$} & \multirow{2}{*}{ PCEs } & \multicolumn{2}{|c|}{ MNPCES } & \multirow{2}{*}{$\begin{array}{c}\text { PCE/NCE } \\
\text { ratio }\end{array}$} \\
\hline & & & $\mathbf{N}^{\mathbf{0}}$ & $\%$ & \\
\hline Positive control & 12000 & 11982 & 18 & 0.15 & $0.0006^{(\mathrm{c})}$ \\
\hline Negative control & 12000 & 11980 & 20 & 0.17 & $0.02^{(\mathrm{b})}$ \\
\hline Aqueous extract & 12000 & 11989 & 11 & 0.092 & $0.016^{(\mathrm{a})}$ \\
\hline
\end{tabular}

(a) (b) and (c) different letters in the same column differ from each other $(\mathrm{P}<0.05)$ according to the $\chi^{2}$ test; PCEs - polychromatic erythrocytes; NCE - normochromatic erythrocytes; MNPCEs - micronucleated polychromatic erythrocytes

The analyses carried out $48 \mathrm{~h}$ (Table III) and $72 \mathrm{~h}$ (Table IV) after treatment demonstrated that the extract did not have genotoxic potential. At 48 hours after treatment, the number of micronucleated PCEs in the mice treated with the extract was significantly lower than in the positive control animals.

In the examination performed $72 \mathrm{~h}$ after treatment, there was a reduction in the number of micronucleated PCEs in the positive control group, indicating that after this interval, the genotoxic potential of the positive control group could no longer be perceived by the presence of micronucleated erythrocytes in the peripheral blood.

Although no genotoxic potential of the extract was detected, there was a significant difference in the $\mathrm{PCE} / \mathrm{NCE}$ ratio between the treatments. The animals treated with the extract presented a significantly lower ratio between PCEs and NCEs compared to the negative control group, indicating cytotoxic activity of the extract.

\section{Phytochemical analysis of the extract}

The phytochemical analysis of the extract detected the presence of reducing sugars, saponins, phenolic compounds, purines, flavonoids (flavones, flavonols, xanthones) and alkaloids, as presented in Table V.

\section{Analysis of total flavonoids and phenolics contents}

The results from analysis obtained from $6.8 \mathrm{~g}$ of the dry extract of $L$. nobilis leaves were $16.10 \pm 0.001 \mathrm{mg}$
TABLE V - Phytochemical analysis of aqueous extract of L. nobilis leaves

\begin{tabular}{lc}
\hline Secondary compounds & Aqueous extract \\
\hline Quinones & - \\
Reducing sugars & + \\
Saponins & + \\
Sesquiterpenlactones and other lactones & - \\
Steroids and triterpenoids & - \\
Cardiac glycosides & - \\
Polysaccharides & - \\
Purines & + \\
Alkaloids & + \\
Flavones, flavonoids and xanthones & + \\
Phenolic tannins & + \\
\hline
\end{tabular}

(-) Absence or inconclusive, $(+)$ Presence

equivalents in Quercetin/g extract for total flavonoids and $95.5 \pm 0.001 \mathrm{mg}$ equivalents in Gallic acid/g extract for total phenolics contents.

\section{DISCUSSION}

The results obtained in this study demonstrated that the aqueous extract of $L$. nobilis leaves, at the two concentrations tested, does not present genotoxic effect. However, cytotoxic activity was detected according to the two evaluation methods. 
The extract caused a significant reduction in the mitotic index of the meristematic cells of $A$. cepa and also significantly lowered the PCE/NCE ratio in the mice's peripheral blood. Besides this, we observed the presence of cytotoxic effects of the extract on the meristematic cells of $A$. cepa, with a high index of cells undergoing apoptosis and with nuclear alterations related to cell death processes.

The presence of cytotoxic effects without genotoxicity is a common observation, reported in several articles (Chichioco-Hernandez et al., 2011; Eren et al., 2015; Gomes et al., 2015; Lima et al., 2016). According to Oliveira, Voltolini and Barbério (2011), cytotoxicity can lead indirectly to alterations in the genetic material, but is not necessarily associated with a genotoxic effect.

There are reports of the absence of genotoxicity accompanied by antimutagenic effect (Tavares et al., 2011; Lima et al., 2013a). In the current study, the aqueous extract at the two concentrations significantly reduced the number of buds and caused alterations in nucleoli, including in relation to the negative control group. These changes are characteristic of agents with genotoxic potential, such as the positive control used in this study (Montanaro, Treré, Derenzini, 2008; Fenech et al., 2011; Kumar, Chaudhary, 2015). The reduction of these alterations in the cells treated with the extract indicates that it has a protective effect. The phytochemical analysis of the crude aqueous extract of the L. nobilis leaves conducted in this work demonstrated the presence of antioxidant compounds, such as phenolic tannins and total phenolic, flavones, flavonoids, xanthones and total flavonoids, which likely explains the protective or antigenotoxic effect observed.

Similar results have been obtained by other authors. Kaurinovic, Popovic and Vlaisavljevic (2010) demonstrated that the methanol extract of $L$. nobilis leaves re-extracted with ethyl acetate, had strong activity to eliminate free radicals in vitro and a protective effect in vivo when analyzing the biochemical pattern of the blood and liver of mice treated with the extract. The authors attributed this effect to the presence of flavonoids and sesquiterpenes in the extract. Rood et al. (2015) used gel filtration chromatography to divide a bay leaf extract into two fractions, one with high molecular weight (HFBL) and the other with low molecular weight (LFBL). The dried fractions prepared in ethanol were tested in cell cultures and the presence was noted of distinct biological activities of the two fractions. An antioxidant protective effect was present in the LFBL (rich in polyphenols) but absent in the HFBL (probably rich in polysaccharides).

We observed a significant number of cells undergoing apoptosis and with nuclear alterations related to cell death processes in the A. cepa assays with the two extract concentrations (Tables I and II).

The nuclear alterations, observed in large number in the meristematic cells of A. cepa, are similar to karyorrhexis. These alterations are present in cells in the death process by necrosis or apoptosis, in which the chromatin is irregularly distributed, including the formation of lumps in the nuclear membrane (Tolbert, Shy, Allen, 1992; Thomas et al., 2008; Lima et al., 2016).

The inducement of apoptosis by L. nobilis has been reported by other authors with other types of extracts. Pacífico et al. (2013), working with apolar extracts of $L$. nobilis leaves, reported strong toxicity and inducement of apoptosis in cell lines from the nervous system. Those observations indicate the existence of components in the apolar and aqueous extracts of $L$. nobilis leaves that have cytotoxic potential and induce apoptosis.

Rood et al. (2015), investigating HFBL and LFBL fractions, described that the fraction with high molecular weight induced apoptosis faster by producing ruptures in the DNA double strand, while the fraction with low molecular weight protected the DNA against damages and inducing a delayed apoptosis, promoting a stop in the cell cycle in the $\mathrm{G} 1 / \mathrm{S}$ phase.

Our phytochemical analysis did not detect the presence of polysaccharides. However, phenolic compounds were found, which can explain the high rate of cells undergoing death and the antiproliferative effect of the extract, observed by the reduction of the mitotic index in the Allium cepa assay and the reduction of the PCE/ NCE ratio in the micronucleus test. However, we cannot discard the possibility that those effects were influenced by the presence of saponins and alkaloids, detected by the phytochemical analysis of the extract.

Saponins are products of the secondary metabolism with wide structural variability. Many classes of saponins have been found to have some type of antitumoral activity, in some cases acting by inhibiting the cell cycle and inducing apoptosis (Upadhyay, Singh, 2012).

The phytochemical pattern of L. noblis has been extensively studied and the presence of alkaloids has been identified by other authors (Pech, Bruneton, 1982). Alkaloids are potentially cytotoxic, besides having antifungal and antibacterial activities (Patel et al., 2012; Cushnie, Cushnie, Lamb, 2014).

In the analysis of the meristematic cells of $A$. cepa, although both concentrations caused a reduction in the number of cells undergoing division, this difference was significantly lower in relation to the positive and negative controls only with the concentration of $15 \mathrm{mg} \mathrm{mL}^{-1}$.

This difference in the effects on the mitotic index 
when analyzing two extract concentrations is commonly observed in studies of crude plant extracts, because aqueous extracts at different concentrations present variable interactions of their components, so there is no direct correlation between the increase of concentration and a proportional increase of the extract's effects. Similar results have been reported by other researchers (Celik, 2012; Udo, Akpan, Ekong, 2015).

The results obtained by the peripheral blood mononuclear cell test confirmed the absence of genotoxic potential of the extract and its cytotoxicity. It should be stressed, however, that 72 hours after the treatment, the positive control no longer showed a significant difference regarding the presence of micronuclei in relation to the other treatments, indicating that although this is within the range of time recommended by the OECD TG 474 (2014), it is not efficient to analyze the results when using cyclophosphamide as positive control at a concentration of $50 \mathrm{mg} / \mathrm{kg}$. A reduction of the number of micronucleated erythrocytes with longer time interval after application of the drug has also been reported by other authors (Berno et al., 2016; Schneider et al., 2016).

The number of animals used in these experiments sought to comply with the standards of the Ethics Committee on Animal Use of the Biological Sciences and Health Institute of UFRRJ and to conform to the Principle of the 3R's, besides accompanying the recent references of other authors (Andrade, Perazzo, Maistro, 2008a; Andrade et al, 2008b; Agrawal, Pandely, 2009; Alves et al 2014).

It is also important to stress that the results indicate the relevance of studies using plant systems, such as the A. cepa assay, due to the close similarity with the results of animal tests, as can also be observed in other works (Teixeira et al., 2003; Rainho et al., 2010, Lima et al., 2013b).

In conclusion, the results obtained in this study, through the two methods applied, indicate that the aqueous extract of the leaves of L. nobilis at the two concentrations analyzed does not pose risks regarding genotoxic potential. Besides this, the extract contains components with apoptotic and antigenotoxic potential, further evidencing its richness regarding the presence of substances with relevant biological activities.

The similarity of the results obtained through the two methods studied indicates the importance of using the $A$. cepa assay for initial screening to evaluate the cytotoxic and genotoxic potential of plant extracts.

\section{ACKNOWLEDGEMENTS}

We gratefully acknowledge the herbarium technician
Thiago Azevedo Amorim of the Botany Department of Federal Rural University of Rio de Janeiro (UFRRJ) for the recognition of botanical material and to Dr. Rosane Nora Casto of the Chemistry Department of UFRRJ for analysis of total flavonoids and phenolics.

\section{REFERENCES}

Agrawal RC, Pandey S. Evaluation of anticarcinogenic and antimutagenic potential of Bauhinia variegata extract in Swiss albino mice. Asian Pacific J Cancer Prev. 2009;10(5):913-916.

Alves ABCR, dos Santos RS, Calil S.eS, Niero R, Lopes J.aS, Perazzo FF, et al. Genotoxic assessment of Rubus imperialis (Rosaceae) extract in vivo and its potencial chemoprevention against cyclophosphamide-induced DNA damage. J Ethnopharmacol. 2014;153(3):694-700.

Andrade CUB, Perazzo FF, Maistro EL. Mutagenicity of the Musa paradisiaca (Musaceae) fruit peel extract in mouse peripheral blood cells in vivo. Genet Mol Res. 2008a;7(3):725732.

Andrade LS, Santos DB, Castro DB, Guillo LA, Chen-Chen L. Absence of antimutagenicity of Cochlospermum regium (Mart. And Schr.) Pilger 1924 by micronucleus test in mice. Braz J Biol. 2008b;68(1):155-159.

Barroso MF, Noronha JP, Delerue-Matos C, Oliveira MBPP. Flavored waters: Influence of ingredients on antioxidant capacity and terpenoid profile by HS-SPME/GC-MS. $J$ Agric Food Chem. 2011;59(9):5062-5072.

Berno CR, Ros BdeT, da Silveira IO, Coelho HR, Antoniolli AC, Beatriz A, et al. 4-Aminoantipyrine reduces toxic and genotoxic effects of doxorubicin, cisplatin, and cyclophosphamide in male mice. Mutat Res Genet Toxicol Environ Mutagen. 2016;805:1924.

Cai LY, Shi FX, Gao X. Preliminary phytochemical analysis of Acanthopanan trifoliatus (L.) Merr. J Med Plant Res. 2011;5(17):4059-4064.

Castro LS, Perazzo FF, Maistro EL. Genotoxicity testing of Ambelania occidentalis (Apocynaceae) leaf extract in vivo. Genet Mol Res. 2009;8(2):440-447.

Celik TA. Potential genotoxic and cytotoxic effects of plant extracts. In: Bhattacharya A, editor. A compendium of essays on alternative therapy. InTech; 2012. p. 233-250. DOI: $10.5772 / 28488$. 
Chichioco-Hernandez C, Wudarski J, Gevaert L, Verschaeve L. Evaluation of cytotoxicity and genotoxicity of some Philippine medicinal plantas. Pharmacogn Mag. 2011;7(26):171-175.

Cushnie TP, Cushnie B, Lamb AJ. Alkaloids: an overview of their antibacterial, antibiotic-enhancing and antivirulence activities. Int J Antimicrob Agents. 2014;44(5):377-386.

de Castro E Sousa JM, Peron AP, da Silva E Sousa L, Holanda MM, Lima AMV, de Oliveira VA, et al. Cytotoxicity and genotoxicity of Guaribas river water (Piauí, Brazil), influenced by anthropogenic action. Environ Monit Assess. 2017;189(6):111.

Dias MI, Barreira JC, Calhelha RC, Queiroz MJ, Oliveira MB, Soković M, et al. Two-dimensional PCA highlights the differentiated antitumor and antimicrobial activity of methanolic and aqueous extracts of Laurus nobilis L. from different origins. Biomed Res Int. 2014;2014:1-10.

Eren Y, Erdgmus SF, Akyl D, Ozkara A, Konuk M, Saglam E. Cytotoxic and genotoxic effects of dioxacarb by human peripheral blood lymphocytes Cas and Allium test. Cytotechnology. 2015;67:1023-1030.

Fenech M, Kirsch-Volders M, Natarajan AT, Surralles J, Crott JW, Parry J, et al. Molecular mechanisms of micronucleus, nucleoplasmic bridge and nuclear bud formation in mammalian and human cells. Mutagenesis. 2011;26(1):125-132.

Gomes JV, Teixeira JTdS, Lima VMd, Borba HR. Induction of cytotoxic and genotoxic effects of Guandu River Waters in the Allium cepa system. Rev Ambient Água. 2015;10(1):49-58.

Kaurinovic B, Popovic M, Vlaisavljevic S. In vitro and in vivo effects of Laurus nobilis L. leaf extracts. Molecules. 2010;15(5):3378-3390.

Kivcak B, Mert T. Preliminary evaluation of cytotoxic properties of Laurus nobilis leaf extracts. Fitoterapia 2002;73(3):242-243.

Kumar G, Chaudhary N. Nuclear blebs assay for genome instability in Phaseolus vulgaris L. Cytologia. 2015;80(4):505512.

Lima VM, Teixeira JTS, Gomes JV, Mello MS, Fampa P, Borba HR. Evaluation of genotoxicity of Solanum lycocarpum aqueous extract utilizing Allium cepa test-system. In: Proceedings of the 10th Internationl Congress on Cell Biology and 16th Meeting of Brazilian Society for Cell Biology. 2012 Jul 25-28; Rio de Janeiro - Brasil; 2013a. p 73-78.
Lima VM, Teixeira JTS, Gomes JV, Almeida LK, Bastos LO, Santos HLC, et al. Joannesia princeps: Evaluation of Aqueous Extracts Genotoxicity Utilizing Allium cepa Assay and Micronucleus Test. J Life Sci. 2013b;7(12):1249-1254.

Lima VM, Gomes JV, Matos AF, Pereira GL, Larangeira MdJC, Borba HR. Mangifera indica L.: Evaluation of the cytotoxic and genotoxic potencial of the aqueous extract by the Allium cepa test. WJPR. 2016;5:9.

Macêdo MFS, Sisenando HAAACN, Queiroz JDF, Argolo ACC, Saturnino ACRD, Coelho LCBB, et al. Determining the genotoxicity of an aqueous infusion of Bauhinia monandra leaves. Rev Bras Farmacogn. 2008;18(4):509-516.

Matos FJA. Introdução à fitoquímica experimental. 3 ed. Fortaleza: Editora UFC; 2009. 150 p.

Morsy N. Phytochemical analysis of biologically active constituents of medicinal plants. Main Group Chem. 2014;13:7-21.

Montanaro L, Treré D, Derenzini M. Nucleolus, ribosomes, and cancer. Am J Path. 2008;173(2):301-310.

OECD TG 474. Guideline for the testing of chemicals. Mammalian erythrocyte micronucleus test. 2014. Available from: http://www.oecd.org/chemicalsafety/risk-assessment/1948442. pdf.

Oliveira LMd, Voltolini JC, Barbério A. Potencial mutagênico dos poluentes na água do rio Paraíba do Sul em Tremembé, SP, Brasil, utilizando o teste Allium cepa. Rev Ambient Água. 2011;6(1):90-103.

Pacifico S, Gallicchio M, Lorenz P, Potenza N, Galasso S, Marciano S, et al. Apolar Laurus nobilis leaf extracts induce cytotoxicity and apoptosis towards three nervous system cell lines. Food Chem Toxicol. 2013;62:628-637.

Patel K, Gadewar M, Tripathi R, Prasad SK, Patel DK. A review on medicinal importance, pharmacological activity and bioanalytical aspects of beta-carboline alkaloid "Harmine". Asian Pac J Trop Biomed. 2012;2(8):660-664.

Pech B, Bruneton J. Alcaloides Du Laurier Noble, Laurus nobilis. J Nat Prod. 1982;45(5):560-563.

Peixoto LR, Rosalen PL, Ferreira GL, Freires IA, de Carvalho FG, Castellano LR, et al. Antifungal activity, mode of action and anti-biofilm effects of Laurus nobilis Linnaeus essential oil against Candida spp. Arch Oral Biol. 2017;73:179-185. 
Rafiq R, Hayek SA, Anyanwu U, Hardy BI, Giddings VL, Ibrahim SA, et al. Antibacterial and Antioxidant Activities of Essential Oils from Artemisia herba-alba Asso., Pelargonium capitatum $\mathrm{x}$ radens and Laurus nobilis L. Foods. 2016;5(28):112.

Rainho CR, Kaezer A, Aiub CAF, Felzenszwalb I. Ability of Allium cepa L. root tips and Tradescantia pallida var. purpurea in $N$-nitrosodiethylamine genotoxicity and mutagenicity evaluation. An Acad Bras Cienc. 2010;82(4):925-932.

Rodd AL, Ververis K, Sayakkarage D, Khan AW, Rafehi H, Ziemann M, et al. RNA sequencing supports distinct reactive oxygen species-mediated pathways of apoptosis by high and low size mass fractions of Bay leaf (Lauris nobilis) in HT-29 cells. Food Funct. 2015;6(8):2507-2524.

Salgueiro FB, Castro RN. Comparação entre a composição química e capacidade antioxidante de diferentes extratos de próprolis verde. Quim Nova. 2016;39(10):1192-1199.

Schneider BU, Meza A, Beatriz A, Pesarini JR, Carvalho PC, Mauro Mde O, et al. Cardanol: toxicogenetic assessment and its effects when combined with cyclophosphamide. Genet Mol Biol. 2016;39(2):279-289.

Tavares DC, Munari CC, Araújo MGdF, Beltrame MC, Furtado MA, Gonçalves CC, et al. Antimutagenic potential of Solanum lycocarpum against induction of chromosomal aberrations in V79 cells and micronuclei in mice by doxorubicin. Planta Med. 2011;77(13):1489-1494.
Teixeira RdO, Camparoto ML, Mantovani MS, Vincentini VEP. Assessment of two medicinal plantas, Psidium guajava L. and Achillea millefolium L., in in vitro and in vivo assays. Genet Mol Biol. 2003;26(4):551-555.

Thomas P, Harvey S, Gruner T, Fenech M. The buccal cytome and micronucleus frequency is substantially altered in Down's syndrome and normal ageing compared to young healthy controls. Mutat Res. 2008;638(1-2):37-47.

Tolbert PE, Shy CM, Allen JW. Micronuclei and other nuclear anomalies in buccal smears:methods development. Mutat Res. 1992;271(1):69-77.

Trease GE, Evans WC. Pharmacognosy. 16th edition. London: Scandars Company Ltd; 1989. 603 p.

Udo IJ, Akpan GA, Ekong NJ. Cytotoxic effects of alcoholic extracts of 5 medicinal plants on mitosis in Allium cepa root tips after $12 \mathrm{~h}$ recovery from $24 \mathrm{~h}$ treatments. J Med Plants Stud. 2015;3(2):114-117.

Upadhyay A, Singh DK. Pharmacological effects of Sapindus mukorossi. Rev Inst Med Trop Sao Paulo. 2012;54(5):273-280.

Veronez B, Sato ME, Nicastro RL. Toxicidade de compostos sintéticos e naturais sobre Tetranychus urticae e o predador Phytoseiulus macropilis. Pesq Agropec Bras. 2012;47(4):511518 .

Received for publication on $17^{\text {th }}$ April 2018 Accepted for publication on $27^{\text {th }}$ June 2018 